ORIGINALS ( 2 )

\title{
$\mathrm{CO}$ の水素化における Fe-Co-Ni 系複合金属触媒の物性
}

\author{
石原達已・江口浩一・荒井弘通 \\ 九州大学大学院総合理工学研究科 $\bar{T} 816$ 福岡県春日市春日公園 6-1
}

(1986 年 6 月 16 日受理)

\section{Catalytic Properties of Iron, Cobalt, and Nickel Ternary System Catalysts for Carbon Monoxide Hydrogenation}

\author{
Tatsumi ISHIHARA, Koichi EGUCHI and Hiromichi ARAI \\ Graduate School of Engineering Sciences, Department of Materials \\ Science and Technology, Kyusyu University \\ Kasugakôen 6-1, Kasuga-shi, Fukuoka 816
}

(Received June 16, 1986)

\begin{abstract}
Catalytic properties of supported $\mathrm{Fe}, \mathrm{Co}$, and $\mathrm{Ni}$ bimetallic catalysts were examined with XPS, XRD, and IR. From the XPS and catalyst's XRD measurements, it become evident that the reducibility of iron or cobalt was enhanced by alloying with nickel. This reducibility enhancement suggests that hydrogen is easily activated on the catalyst's surface. Infrared spectra of NO adsorbed on bimetallic catalysts depended on the metal composition. The conversion of $\mathrm{CO}$ was related with the absorbance of bent-type NO. Adsorption sites of bent-type were expected to be active sites in $\mathrm{CO}$ hydrogenation because of its high electron density. The alloying metals increased the absorbance of bent-type resulting in high $\mathrm{CO}$ conversion and high selectivity to higher hydrocarbons.
\end{abstract}

\section{1.はじめに}

Shultz-Flory 則に支配される Fischer-Tropsch 合成 は生成物分布が広い範囲にわたり経済的に好ましくな い。そこで現在 $\mathrm{CO}$ の水素化反応では高活性で, しか あ望ましい生成物を高選択的に合成する触媒の開発が強 く望まれている。担持複合金属触媒は主に金属間の電子 的相互作用により, CO の水素化反応において活性, 選 択性および寿命に著しい効果を及ぼすととがある”。し かし一酸化炭素の水素化反応飞担持複合金属触媒を用い た例は非常に少ない2 2 9)。 $\mathrm{SiO}_{2}$ 担持触媒では $\mathrm{Fe}$ は $\mathrm{Co}$ に比べてオレフィンと含酸素化合物を生成し易いが, 一 方反応中にカーバイトを生成し易い。Co は CO 転化率 が最も高く，また Ni は Co と Fe に比べてメタンを高 選択的に合成する ${ }^{10)}$ 。乙のように触媒作用の異なる第UIII 族金属の複合化により，特徽的な性質を示す新しい系の 触媒の開発が期待される。

我々は従来の研究において $\mathrm{SiO}_{2}$ 预よび $\mathrm{TiO}_{2}$ に担持

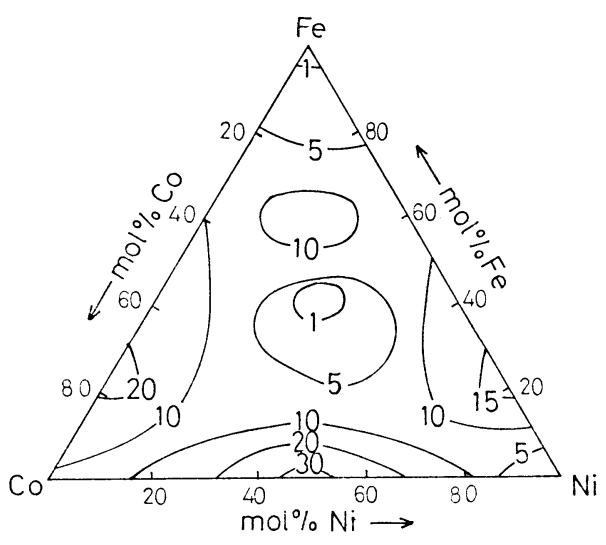

Fig. $1 \mathrm{CO}$ conversion as function of compo. sition in the ternary system of $\mathrm{Fe}-\mathrm{Co}-\mathrm{Ni} / \mathrm{SiO}_{2}$. $\left(523 \mathrm{~K}, 1.0 \mathrm{MPa}, \mathrm{H}_{2} / \mathrm{CO}=1.9, \mathrm{~W} / \mathrm{F}=10\right.$ g-cal $\mathrm{h} / \mathrm{mol})$ 


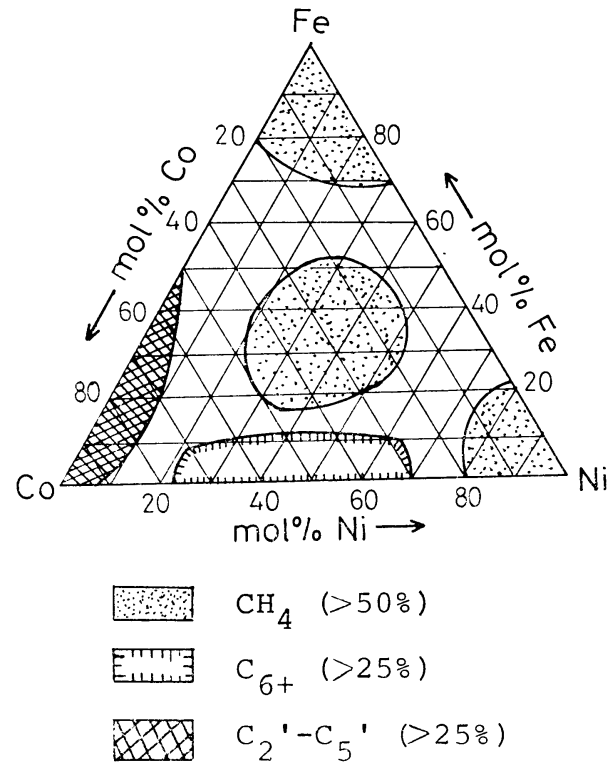

Fig. 2 Selectivity as a function of composition in the ternary system of $\mathrm{Fe}-\mathrm{Co}-\mathrm{Ni} / \mathrm{SiO}_{2}$.

した $\mathrm{Fe}-\mathrm{Co}-\mathrm{Ni}$ 系複合金属触媒を用い $\mathrm{CO}$ の水素化反 応を行なった ${ }^{11,12)}$ 。 $\mathrm{Fe}, \mathrm{Co}, \mathrm{Ni}$ は複合化することによ り活性は向上し，優れた生成物分布が得られる。 $\mathrm{TiO}_{2}$ 担持触媒における $\mathrm{CO}$ の転化率は $\mathrm{Fe}, \mathrm{Co}, \mathrm{Ni}$ の全ての 合金金属組成領域において $\mathrm{SiO}_{2}$ 担持触媒より高いが， 活性な組成領域は $\mathrm{SiO}_{2}$ 担持触媒系之殆ど同じ組成であ った。Fig. 1 に例として $\mathrm{SiO}_{2}$ 担持触媒における $\mathrm{CO}$ 転化率の金属組成依存性を示す。Co と $\mathrm{Ni}$ が多く含ま れる組成領域では $\mathrm{CO}$ の水素化活性は高く, 一方, $\mathrm{Fe}$ の多い組成領域では活性は低い。生成物の選択性は担体 の種類によらず，主に金属の組成に依存した。Fig.2 に $\mathrm{SiO}_{2}$ 担持触媒における生成物分布の金属組成への依 存性を示す。Co-Ni 2 成分系複合金属触媒では連鎖成 長が進み易く, $\mathrm{C}_{2}-\mathrm{C}_{11}$ 選択率は高い。一方, $\mathrm{Fe}-\mathrm{Co} 2$ 成 分系複合金属触媒では $\mathrm{C}_{2}-\mathrm{C}_{5}$ のオレフィンが多く生成 した。Fe，Co，Ni が等モル付近と $\mathrm{Fe}, \mathrm{Ni}$ に富んだ組 成の 3 成分系複合金属触媒ではメタン生成が多くなっ た。このように担持 $\mathrm{Fe}-\mathrm{Co}-\mathrm{Ni}$ 系複合金属触媒では, 活性およで選択性は金属組成により強く影響されること がわかった。本研究では上述したように単一金属触媒 に比べはるかに優れた活性と選択性を有する $\mathrm{Fe}-\mathrm{Co}-\mathrm{Ni}$ 系複合金属触媒に打りる金属の物性を光電子分光法 (XPS), X線回折法 (XRD), 吸着 NO を用いた赤外吸 収法 (IR) で調べ, $\mathrm{CO}$ の水素化反応との関係について検 討した。

\section{2. 実 験}

\section{1 触媒調製}

$\mathrm{SiO}_{2}$ は Aerosil 380 (日本エアロジル社製, BET 表 面積 $\left.380 \mathrm{~m}^{2} / \mathrm{g}\right)$ を用い, $\mathrm{TiO}_{2}$ は四塩化チタン $\left(\mathrm{TiCl}_{4}\right)$ の加水分解により調製した (BET 表面積 $43 \mathrm{~m}^{2} / \mathrm{g}$ )。担 持複合金属触媒は全金属担持量が合わせて $10 \mathrm{wt} \%$ に なるように当量計算した $\mathrm{Fe}\left(\mathrm{NO}_{3}\right)_{3} \cdot 9 \mathrm{H}_{2} \mathrm{O}, \mathrm{Co}\left(\mathrm{NO}_{3}\right)_{2}$. $6 \mathrm{H}_{2} \mathrm{O}, \mathrm{Ni}\left(\mathrm{NO}_{3}\right)_{2} \cdot 6 \mathrm{H}_{2} \mathrm{O}$ を水溶液中で混合し, アンモ 二ア水に上り担体上に共沈させた。蒸発乾固後, $383 \mathrm{~K}$ で $12 \mathrm{~h}$ 乾燥した。触媒は錠剤成型器で $20 \mathrm{~mm} \phi$ のディ スク状に圧縮 $\left(200 \mathrm{~kg} / \mathrm{m}^{2}\right)$ 成型した後, 粉砕し，10-20 メッシュにそ万えた。その後, $573 \mathrm{~K} 4$ 時間, 空気気流 中で焼成した後, $573 \mathrm{~K} 2$ 時間㧍よび $673 \mathrm{~K} 2$ 時間の 水素還元を行なった。

\section{2 吸着 NO の IR 測定}

吸着 NO の IR 測定は空材に $\mathrm{CaF}_{2}$ を用いたパイレ ックス製セルを用い，透過法で行なった。セルは真空系 とボールジョイントで連結しており，0.67 Pa まで真空 排気が行なえる。また測定部の上部に電気炉を供えてお り, 触媒を移動し, 所定の温度処理も行なえる。赤外分 光器には日本分光 (株) 製 IR-810を用いた。還元後の触 媒約 $30 \mathrm{mg}$ を $20 \mathrm{~mm} \phi$ のディスク状に圧縮成型した 後, 前処理として $400^{\circ} \mathrm{C}, 3$ 時間, $0.67 \mathrm{~Pa}$ で真空排気 を行なった。その後, 室温まで泠却し, 触媒自身の IR 測定を行ない, バックグラウンドとした。室温で，NO 約 $4 \mathrm{kPa}$ を導入し, $100^{\circ} \mathrm{C}, 30$ 分間加熱後, 室温まで泠 却し, NO 排気捘, IR 測定を行ない吸着 NOの IR ス ペクトルを得た。吸着 NO の吸収スペクトルはいずれ も触媒のバックグラウンドを差し引いて示した。

\section{3. 結果および考察}

\section{1 担持金属の状態}

$\mathrm{Fe}$ の昇華熱は他の金属と比較して小さく, Fe を含む 複合金属では Fe の Surface Segregation が多数報告さ れている ${ }^{9,13)}$ 。 Fe は金属への還元反応の標準ギブス自由 エネルギ $\left(\Delta G^{\circ}\right)$ あ $\mathrm{Co}, \mathrm{Ni}$ に比較して大きく, 容易に

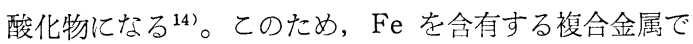
は， Fe の状態分析は非常に重要となる。本研究では複 合金属触媒の表面における各金属成分の状態を光電子分 光法 (XPS) およびX線回折法 (XRD) により調べた。

XPS は線源に Mg K $\alpha$ を用い, $10 \mathrm{wt} \%$ および 50 $\mathrm{wt} \%$ 担持複合金属触媒の各金属の $2 \mathrm{p}_{3 / 2}$ レベルについ て測定を行なった。測定前に表面不純物層を取り除くた めに 10 分間 $\mathrm{Ar}$ スパッタを行なった。測定後金荐着 し, Binding Energy の補正を行なった。 


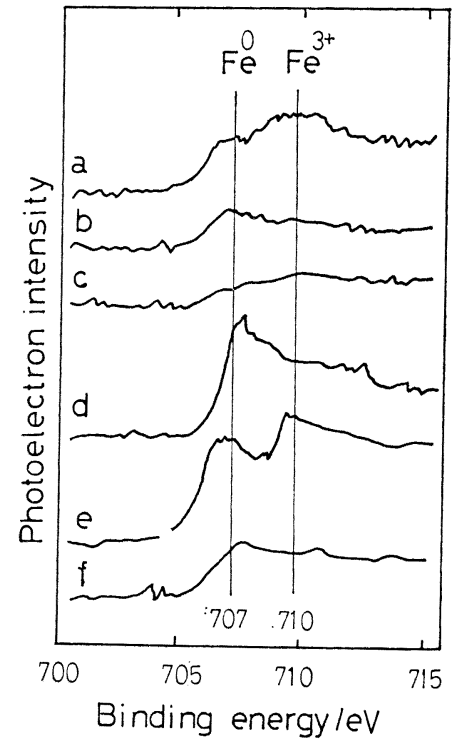

Fig. 3 XPS spectra of $\mathrm{Fe} 2 \mathrm{p}_{3 / 2}$ over $\mathrm{TiO}_{2}$-supported $\mathrm{Fe}-\mathrm{Co}-\mathrm{Ni}$ alloy catalysts. a: $\mathrm{Fe}(10$ wt\%) b: $50 \mathrm{Fe} 50 \mathrm{Co}(10 \mathrm{wt} \%) \quad \mathrm{c}: 50 \mathrm{Fe} 50 \mathrm{Ni}$ (10 wt\%) d: $50 \mathrm{Fe} 50 \mathrm{Co}(50 \mathrm{wt} \%)$ e : $50 \mathrm{Fe} 50$ $\mathrm{Ni}(50 \mathrm{wt} \%)$ f : $33 \mathrm{Fe} 33 \mathrm{Co} 33 \mathrm{Ni}(50$ wt $\%)$

$\mathrm{Fe}$ を含有する $\mathrm{TiO}_{2}$ 担持触媒における XPS スペク トルは Fig. 3 に示すように, $707 \mathrm{eV}$ に0 価, $710 \mathrm{eV}$ に3価に帰属されるピークが現われた。 $\mathrm{Fe} / \mathrm{TiO}_{2}$ では $707 \mathrm{eV}$ の0 価のピークは小さく，大部分は 3 価であっ た。しかし，10 wt\% および $50 \mathrm{wt} \%$ の $50 \mathrm{Fe} 50 \mathrm{Co}$ お よび $50 \mathrm{Fe} 50 \mathrm{Ni}$ 複合金属では $710 \mathrm{eV}$ の 3 価のピーク は小さく, 大部分 $707 \mathrm{eV}$ の $\mathrm{Fe}^{0}$ ピークなので $\mathrm{Fe}$ は金 属状態で存在することを示している。この結果から $\mathrm{Fe}$ は Co, Ni との複合化により還元され易くなることがわ かった。XPS の結果から, Co, Ni は単独金属および複 合金属のいずれあ 0 価の状態であった。さらにX線回折 法により $\mathrm{SiO}_{2}$ と $\mathrm{TiO}_{2}$ 担持複合金属触媒の結晶状態に ついて検討した。その結果, $\mathrm{SiO}_{2}$ 担持では $\mathrm{Fe}$ と $\mathrm{Co}$, $\mathrm{TiO}_{2}$ 担持では $\mathrm{Fe}$ がそれぞれ $\mathrm{Fe}_{3} \mathrm{O}_{4}$ および $\mathrm{CoO}$ の酸化 状態であった。しかし, 複合化により酸化物のX線回折 ピークは消失した。このようにX線回折の結果とXPSの 結果とは非常によい一致を示した。以上の結果より $\mathrm{Fe}$, $\mathrm{Co}, \mathrm{Ni}$ の複合化により還元性の向上が明らかになった。 このような金属の複合化により還元され易くなる例は既 飞数例報告されている。Butt らは $\mathrm{SiO}_{2}$ 担持 $\mathrm{Fe}-\mathrm{Ni}$ 系複 合金属触媒における酸化還元サイクルを Mössbauer 分 光法等を用い検討し， $\mathrm{Ni}$ は $\mathrm{Fe}$ の還元を促進するとと を見い出している5 。さらに $\mathrm{Cu}-\mathrm{Pt} や \mathrm{Cu}-\mathrm{Pd}$ において も $\mathrm{Pd}$ および $\mathrm{Pt}$ により $\mathrm{Cu}$ の還元性向上が報告されて
いる ${ }^{14)}$ 。現在のところ複合化による還元性向上の原因は より還元されやすい $\mathrm{Ni}, \mathrm{Pt}$ むしくは $\mathrm{Pd}$ 等が水素を活 性化し, 還元されにくい $\mathrm{Fe}, \mathrm{Cu}$ に供給するためである うと考えられている。我々は $\mathrm{H}_{2}$ と $\mathrm{CO}$ の昇温脱離の結 果から, 担持 $\mathrm{Fe}-\mathrm{Co}-\mathrm{Ni}$ 系複合金属触媒による $\mathrm{CO} の$ 水素化反応は $\mathrm{H}_{2}$ の活性化が $\mathrm{CO}$ の水素化活性の重要な 因子であると報告した ${ }^{12)}$ 。単独金属触媒に比べ $\mathrm{Fe}$, Co $\mathrm{Ni}$ 系複合金属触媒では $\mathrm{H}_{2}$ は活性化されやすい。この ため $\mathrm{Fe}, \mathrm{Co}, \mathrm{Ni}$ 相互の複合化により金属の還元性は向 上し, また高い CO 水素化活性を示すすのと考えられる。

\section{$3.2 \mathrm{SiO}_{2}$ 担持複合金属触媒の吸着サイトの状態}

$\mathrm{NO}$ の電子状態は $\mathrm{CO}$ 分子乙類似しているが, 最も大 きな違いは NO 分子の価電子が奇数 (11 個) なので $\pi^{*}$ 軌道に不対電子 1 個を持ち HOMO となる点にある ${ }^{17)}$ 。 $\mathrm{CO}$ は金属の $\mathrm{d}$ 軌道から電子が $\pi *$ 軌道に供与して吸着 する吸着種しかないが，NOは $\pi^{*}$ 軌道の電子を金属の $\mathrm{d}$ 軌道に供与して吸着する吸着種屯存在市る。したが って NOは CO に比べ触媒表面の吸着サイトの電子状 態を解析するのに適した分子といえる。本研究では吸着 $\mathrm{NO}$ の IR スペクトルより $\mathrm{SiO}_{2}$ 担持複合金属触媒の電 子状態を明らかにし, $\mathrm{CO}$ の水素化反応との関連につい て検討した。

\subsubsection{Co- Ni 系複合金属触媒}

$75 \mathrm{Ni} 25 \mathrm{Co} / \mathrm{SiO}_{2}$ 触媒上の吸着 NO の IR 吸収帯は

Fig. 4 に示すように $1875 \mathrm{~cm}^{-1}$ と $1790 \mathrm{~cm}^{-1}$ に現われ た。昇温排気を行なうと, $1790 \mathrm{~cm}^{-1}$ の吸収帯は $200^{\circ} \mathrm{C}$ でほぼ消失してしまうのに対し，1875 $\mathrm{cm}^{-1}$ の吸収帯は

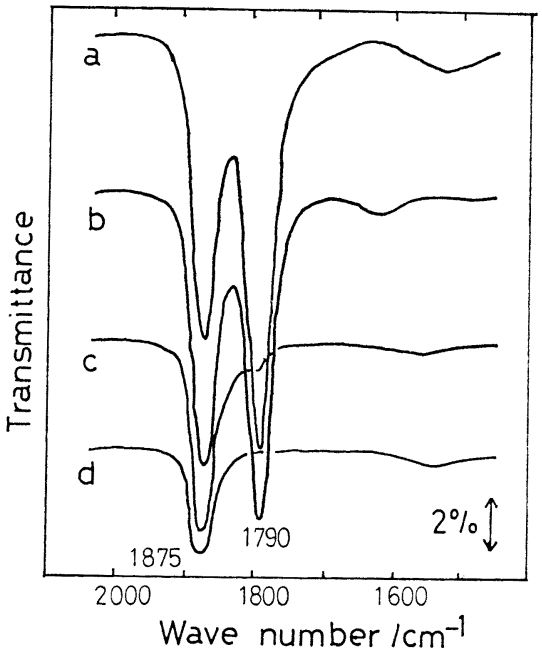

Fig. 4 IR spectra of adsorbed NO after evacuation at various temperature over $75 \mathrm{Ni} 25 \mathrm{Co} /$ $\mathrm{SiO}_{2}$. a : at room temperature $\mathrm{b}$ : at $100^{\circ} \mathrm{C}$ c: at $200^{\circ} \mathrm{C} \mathrm{d}$ : at $300^{\circ} \mathrm{C}$ 
Table 1 Identification of adsorbed NO species over $\mathrm{SiO}_{2}$-supported $\mathrm{Fe}, \mathrm{Co}$, and $\mathrm{Ni}$ bimetallic alloy catalysts.

\begin{tabular}{|c|c|c|c|}
\hline & $\begin{array}{c}\text { Linear type } \\
\left(\mathrm{cm}^{-1}\right)\end{array}$ & $\begin{array}{c}\text { Bent type } \\
\left(\mathrm{cm}^{-1}\right)\end{array}$ & $\begin{array}{l}\text { Unknown } \\
\left(\mathrm{cm}^{-1}\right)\end{array}$ \\
\hline \multicolumn{4}{|l|}{$\mathrm{Fe}-\mathrm{Co}_{\mathrm{O}}$} \\
\hline $\mathrm{Fe}$ & 1915 & 1827 & 1760 \\
\hline $75 \mathrm{Fe} 25 \mathrm{Co}$ & 1888 & 1809 & \\
\hline $50 \mathrm{Fe} 50 \mathrm{Co}$ & 1882 & 1805 & \\
\hline $25 \mathrm{Fe} 75 \mathrm{Co}$ & 1880 & 1795 & \\
\hline Co & 1880 & 1790 & \\
\hline \multicolumn{4}{|l|}{$\mathrm{Co}-\mathrm{Ni}$} \\
\hline Co & 1880 & 1790 & \\
\hline $75 \mathrm{Co} 25 \mathrm{Ni}$ & 1883 & 1800 & \\
\hline $50 \mathrm{Co} 50 \mathrm{Ni}$ & 1865 & 1788 & \\
\hline $25 \mathrm{Co} 75 \mathrm{Ni}$ & 1875 & 1790 & \\
\hline $\mathrm{Ni}$ & 1875 & 1845 & \\
\hline \multicolumn{4}{|l|}{$\mathrm{Ni}-\mathrm{Fe}$} \\
\hline $\mathrm{Ni}$ & 1875 & 1845 & \\
\hline $75 \mathrm{Ni} 25 \mathrm{Fe}$ & 1878 & 1827 & \\
\hline $50 \mathrm{Ni} 50 \mathrm{Fe}$ & 1874 & 1823 & 1748 \\
\hline $25 \mathrm{Ni} 75 \mathrm{Fe}$ & & 1820 & 1755 \\
\hline $\mathrm{Fe}$ & 1915 & 1827 & 1760 \\
\hline
\end{tabular}

$300^{\circ} \mathrm{C}$ 排気後む残存している。したがって, $1790 \mathrm{~cm}^{-1}$,

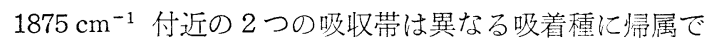
きる。 NO の吸着種には金属の d 轨道より電子が NO の $\pi^{*}$ 軌道に供与される還元状態を表わす Bent 型吸着 種 $\left(\mathrm{NO}^{-}\right)$と, $\mathrm{NO} の \pi^{*}$ 乾道の電子が金属の $\mathrm{d}$ 轨道に 供与さ机万酸化状態を表方す Linear 型吸着種 $\left(\mathrm{NO}^{+}\right)$

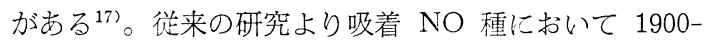
$1700 \mathrm{~cm}^{-1}$ は Linear 型, 1720-1520 $\mathrm{cm}^{-1}$ は Bent 型に それぞれ帰層されている。また同一の吸着種においても 吸着サイトの金属が還元されるほど, 吸収波数は低波数 側にシフトする。本研究においては吸収波数の值から, $1790 \mathrm{~cm}^{-1}$ の吸収帯は Bent 型, $1875 \mathrm{~cm}^{-1}$ の吸収帯は Linear 型の吸着種に帰属した ${ }^{18,19) 。}$

Table 1 亿示すように，Co- $\mathrm{Ni}$ 系に捄いては $\mathrm{Ni}$ 含 有量を増加しても, Bent 型, Linear 型ともに吸着 NO 種の吸収波数には変化はなかった。一方, Bent 型, Linear 型の吸収強度は Fig. 5 に示すように $\mathrm{Ni}$ の含 有量加增加するに伴い両者之屯增加した。しかし, Bent 型と比較し, Linear 型の吸収強度の増加の方が著しい。 Fig. 5 e に示すように $\mathrm{Ni} / \mathrm{SiO}_{2}$ における $\mathrm{NO}$ の吸着種は 殆ど Linear 型である。したがって $\mathrm{Ni}$ の含有量が増加 するとともに複合金属は Ni の強い影響を受に, Linear 型の吸収強度が強くなると考えられる。

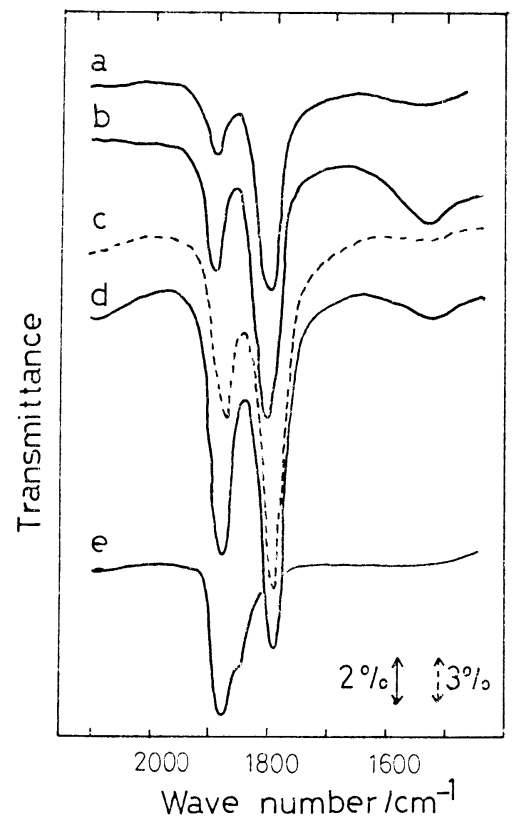

Tig. 5 IR spectra of adsorbed $\mathrm{NO}$ over $\mathrm{SiO}_{2}-$ supported $\mathrm{Co}-\mathrm{Ni}$ bimetallic alloy catalysts. a: Co b: $75 \mathrm{Co} 025 \mathrm{Ni} \quad$ c: $50 \mathrm{Co} 50 \mathrm{Ni}$ d: $25 \mathrm{Co}$ $75 \mathrm{Ni}$ e : $\mathrm{Ni}$

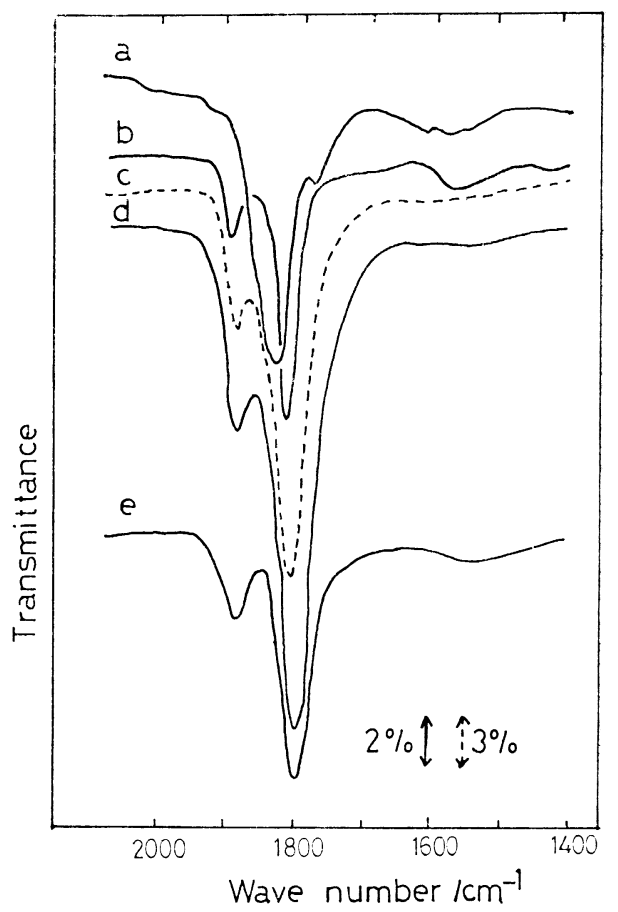

Fig. 6 IR spectra of adsorbed $\mathrm{NO}$ over $\mathrm{SiO}_{2}-$ supported $\mathrm{Fe}-\mathrm{Co}$ bimetallic alloy catalysts. $\mathrm{a}: \mathrm{Fe} \quad \mathrm{b}: 75 \mathrm{Fe} 25 \mathrm{Co} \quad \mathrm{c}: 50 \mathrm{Fe} 50 \mathrm{Co}$ d: $25 \mathrm{Fe} 75$ Co e : Co 


\subsection{2 $\mathrm{Fe}-\mathrm{Co}$ 系複合金属触媒}

$\mathrm{SiO}_{2}$ 担持 $\mathrm{Fe}-\mathrm{Co}$ 系複合金属触媒における吸着 $\mathrm{NO}$ の IR スペクトルは Co- Ni 系と同様に $1800 \mathrm{~cm}^{-1}$ 付近 と $1880 \mathrm{~cm}^{-1}$ 付近に 2 つの吸収帯が現われ，それぞれを Bent 型, Linear 型の吸着種の吸収帯に帰属した（Fig. 6)。Table 1 に示すように Fe-Co 系においては Co 含 有量が多くなるほど Linear 型および Bent 型の吸収波 数は両者と屯低波数側へとシフトした。乙れは触媒か ら吸着 NO 種への電子供与の增加を示している。この 結果はCo 合有量の增加とともに複合金属の電子密度の 増加，すなわち還元状態の強化を示している。ての点で Co の添加はカリウムなどのアルカリ金属の添加効果に 類似している。 Fe-Co 系複合金属触媒では Co の添加に より, $\mathrm{Fe}$ 金属の電子密度加増加するた的 $\mathrm{CO}$ への逆供 与か増し, $\mathrm{CO}$ は解離, 活性化されやすくなると考えら れる。このため, Fe-Co 系複合金属触媒では活性な吸 着 $\mathrm{H}_{2}$ 量に比較し, 活性な吸着 $\mathrm{CO}$ 量が多くなり, オレ フィンを离い選択率で合成するものと理解される。

\section{$3.2 .3 \mathrm{Fe}-\mathrm{Ni}$ 系複合金属触媒}

$\mathrm{SiO}_{2}$ 担持 $\mathrm{Fe}-\mathrm{Ni}$ 系複合金属触媒における吸着 $\mathrm{NO}$ のスペクトルも $1880 \mathrm{~cm}^{-1}$ と $1800 \mathrm{~cm}^{-1}$ に吸収帯が現 われ，それぞれを Linear 型，Bent 型に帰属した。さ らに Fe を多く含有した触媒では $1750 \mathrm{~cm}^{-1}$ にも新しい 吸収带が現われた。Table 1 に示すように Fe-Ni 系で は $\mathrm{Fe} の$ 含有量による吸着種の吸収波数のシフトは認め られなかった。Fig. 7 に示すように Fe-Ni 系では Fe の含有量の堌加ととむに $1880 \mathrm{~cm}^{-1}$ 付近の Linear 型の 吸収強度がさくなり, $1750 \mathrm{~cm}^{-1}$ 付近に新しい吸収带 が現われた。 $1750 \mathrm{~cm}^{-1}$ 付近の吸収帯は Fe に特徵的 な吸收帯で，Fe 讫よび Fe を多く含む触媒にのみ現わ

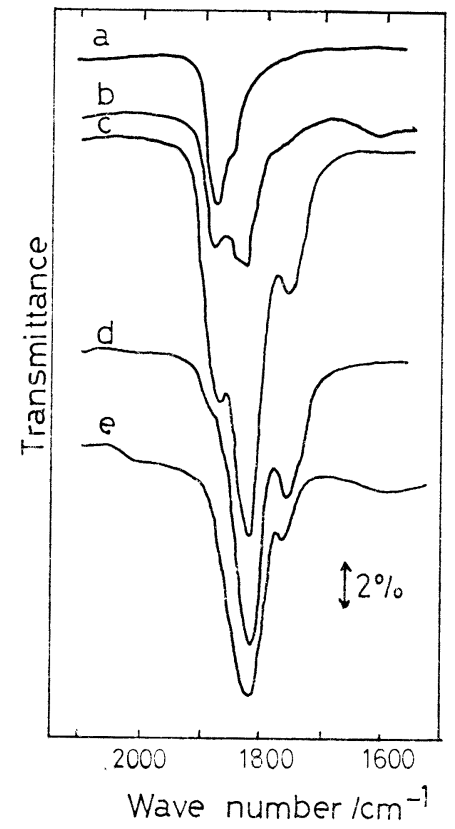

Fig. 7 IR spectra of adsorbed $\mathrm{NO}$ over $\mathrm{SiO}_{2}-$ supported $\mathrm{Ni}-\mathrm{Fe}$ bimetallic alloy catalysts. a : Ni b: $75 \mathrm{Ni} 25 \mathrm{Fe}$ c: $50 \mathrm{Ni} 50 \mathrm{Fe}$ d: $25 \mathrm{Ni} 75$ $\mathrm{Fe}$ e: $\mathrm{Fe}$

れる。したがって Fe の含有量が増えるにしたがい複合 金属は $\mathrm{Fe}$ に強く影響され，複合金属触媒の物性が $\mathrm{Fe}$ に近づくことを示している。

\section{2 .4 吸着サイトの状態と $\mathrm{CO}$ の水素化反応}

Fig. 5，6，7 に示すように金属の組み合わせの違いに より吸着NOのIR スペクトルは大きく異なる。これは 組成変化による金属の電子状態の大きな変化を示してい

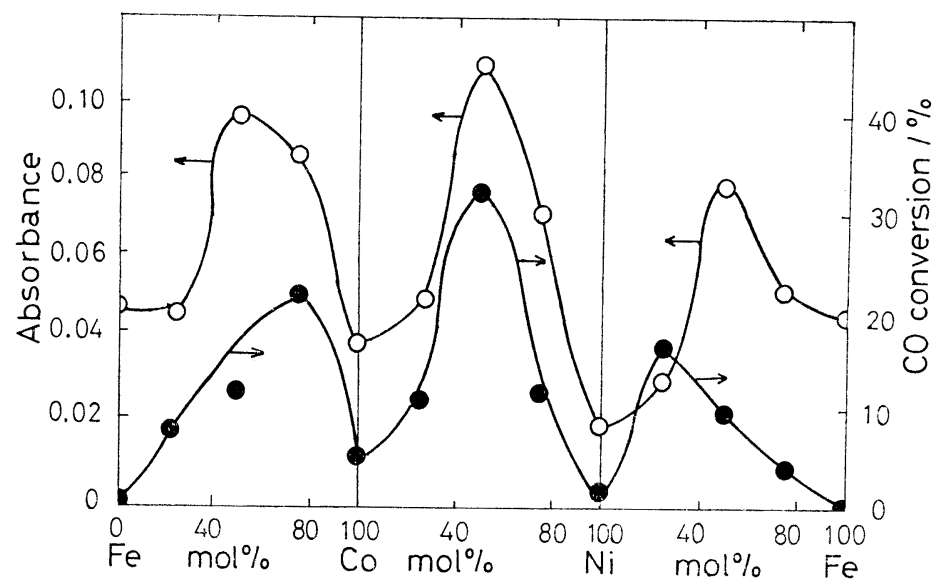

Fig. 8 Relation between $\mathrm{CO}$ conversion and absorbance of adsorbed Bent-type $\mathrm{NO}$ bands over bimetallic catalysts on $\mathrm{SiO}_{2}$ as a function of composition. 
る。こうした金属組成による電子状態の変化により $\mathrm{CO}$ の水素化活性と選択性は大きく影響を受けることを示唆 している。しかむいずれの触媒系においても吸収帯の強 度は金属組成に強く依存している。特に, Bent 型吸収 带は全ての複合金属触媒の吸着 NO の IR スペクトル に現われた。

Fig. 8 亿各触媒系における Bent 型の吸收帯の吸収 強度と $\mathrm{CO}$ 転化率を金属組成に対しプロットした。この 四加ら Bent 型の吸収強度と $\mathrm{CO}$ 転化率は非常によい相 関を示すととがわかる。Bent 型吸着量の多い場合は金 属の電子濃度の高い状態を示している。即ち還元状態ほ ぞ金属の d 軌道加ら吸着分子への逆供与が増加している ので, $\mathrm{H}_{2}$ と $\mathrm{CO}$ は金属強く吸着する。乙のため $\mathrm{H}_{2}$ と $\mathrm{CO}$ は電子濃度の高いサイト上では解離し易く, か つ活性化され易くなる。したがって，電子濃度の高い Bent 型吸着サイトは $\mathrm{CO}$ の水素化反応に打いては重要 な反応サイトと考えられる。Fig. 8 亿示すように Fe, $\mathrm{Co}, \mathrm{Ni}$ 相互の複合化により Bent 型吸着サイト数が增 加する触媒は活性が向上し，しかも連鎖成長が促進され ると考えられる。

\section{4. 結 言}

担持 $\mathrm{Fe}-\mathrm{Co}-\mathrm{Ni}$ 系複合金属触媒の物性を XPS, XRD, IR により検討し，次のような知見を得た。

1) $\mathrm{Fe}, \mathrm{Co}$ は $\mathrm{Ni}$ との複合化により金属への還元性 が向上する。複合金属触媒では， $\mathrm{Fe} ， \mathrm{Co}, \mathrm{Ni}$ はいずれ あ金属状態であるととが確認された。還元性の向上は複 合化により水素が活性化され易くなるためと理解され る。一方, 水素が活性化され易いので, $\mathrm{Fe}-\mathrm{Co}-\mathrm{Ni}$ 系複 合金属触媒は優れた水素活性化能を示す。

2) NO を Probe Molecule として $\mathrm{SiO}_{2}$ 担持複合 金属触媒の電子状態について検討を行なった。金属の組 み合わせの違いにより吸着 NO の IR スペクトルは吸収 波数，吸収強度いずれも顕著に変化した。乙れは金属の 電子状態が大きく変化するととを反映している。いずれ の触媒系においても Bent 型吸着種の吸収強度と $\mathrm{CO}$ 転 化率は良い相関を示すととを明らかにした。電子状態の
高い Bent 型吸着サイトは CO の水素化反応では反広 亿関係する重要なサイトとなると考えられる。 Fe，Co $\mathrm{Ni}$ 相互の複合化によりこの活性サイト数が增加するた め, $\mathrm{CO}$ の水素化反忘において, $\mathrm{Fe}, \mathrm{Co}, \mathrm{Ni}$ 系複合金 属触媒はそれぞれの単一金属触媒に比べ優れた活性，選 択性を示すと考えられる。

\section{文献}

1) R. Burch: Acc. Chem. Res. 1982, 24 (1982).

2) W. N. Delgass, G.L. Ott and T. Fleisch: J. Catal. 60, 394 (1979).

3) G. L. Ott, T. Fleisch and W. N. Delgass : J. Catal. 65, 253 (1980).

4) R. M. Stanfield and W. N. Delgass : J. Catal. 72, 37 (1981).

5) E. E. Unmuth, L. H. Schwartz and J.B. Butt: J. Catal. 72, 37 (1981).

6) E. E. Unmuth, L. H. Schwartz and J. B. Butt : J. Catal. 63, 404 (1980)

7) J.A. Amelse, L. H. Schwartz and J.B. Butt: J. Catal. 72, 95 (1980).

8) K. B. Arcuri, L. H. Schwartz, R. D. Piotrowski and J. B. Butt: J. Catal. 85, 349 (1984).

9) M. Nakamura, B. Y. Hou and H. Wise: "Proc. 7 th. Inter. Congr. Catal." (Tokyo, 1981) p 432.

10) A. T. Bell : Catal. Rev. Eng. 23, 203 (1981).

11) H. Arai, K. Mitsuishi and T. Seiyama: Chem. Lett. 1984, 1291.

12）石原 達己，江口浩一，荒井弘通：触媒 27,407 (1985).

13) M. J. Kelley and V. Ponec. : Prog. in Surf. Sci. 11, 139 (1981).

14) B. D. Macnicol : Catal. Rev.-Sci. Eng. 24, 233 (1982).

15) X. Z. Jiang, S. T. Stevenson and J. A. Dumesic: J. Catal. 91, 11 (1985).

16) X. Z. Jiang, S. J. Stevenson, J. A. Dumesic, T.F. Kelly and R. J. Carson: J. Phys. Chem. 88, 6191 (1984)

17）荒井弘通: 表面 14，427（1976）

18) H. Arai and H. Tominaga: J. Catal. 43, 131 (1976).

19) H. Niiyama and E. Echigoya: J. Catal. 38, 238 (1975). 